\title{
Interview with Lenny Abrahamson and Mark O'Halloran
}

\author{
By Tony Tracy
}

Fall 2008 Issue of KINEMA

\section{IN SEARCH OF THE SUBTEXT: INTERVIEW WITH LENNY ABRAHAMSON AND MARK O'HALLORAN}

DIRECTOR Lenny Abrahamson and writer Mark O'Halloran are widely acknowledged as two of the most original and exciting young voices in Irish cinema. They first collaborated on Adam and Paul (2004); a bleak but also blackly-humorous portrait of Dublin drug addicts caught in a spiral of fixes and failures. This grim scenario was substantially leavened by quirky and unexpected interludes of absurd dialogue and situations interspersed with moments of tenderness and genuine sympathy for the protagonists' hopeless fate. The film marked a return to working class themes and characters in Irish cinema and signalled a departure from the generic and rural narratives that increasingly dominated Irish film production during the 1990s. The film's originality and sophisticated sensibility was acknowledged in its widespread success at film festivals and among the Irish viewing public and it has since travelled widely though international DVD distribution. This impressive debut was followed by their second collaboration, Garage (2007) which forms the basis of the interview that follows.

The most recent collaboration of Abrahamson and O'Halloran was the TV mini-series Prosperity, a four hour exploration of the marginal inhabitants of contemporary Dublin made for the state broadcaster RTÉ in 200\%. In its engagement with issues such as poverty and immigration, Prosperity shared with Adam and Paul an interest in the largely unrepresented underbelly of the "Celtic Tiger" but was more overtly political in its lack of humour and tragic tone. Garage, by contrast, while it is set in a recognisably Irish milieu is less concerned with the socio-political than the private. While Adam and Paul was entirely set in the public sphere telling a picaresque tale of wandering outcasts, Garage focuses on the long acknowledged though infrequently explored theme of loneliness among middle-aged single men in rural Ireland. Its slender plot follows the plight of a simple and unworldly central character named Josie (powerfully played against type by Irish comedian Pat Shortt) who lives and works in a run-down gas station in the Irish midlands. Josie has an unrequited crush on local shop-girl (Anne-Marie Duff) and is the victim of a bully (Don Wycherley) in his local pub. When the petrol-station's owner (John Gallagher) installs the son of his girlfriend on a summer job, Josie does his best to befriend the teenager, but his awkward and inappropriate attempt to connect with the boy results in disastrous consequences.

Garage, like the earlier collaborations of Abrahamson/O'Halloran displays a European sensibility and form; a non-generic storyline centred on an unremarkable character told in a simple, fluid style that echoes directors such as Robert Bresson (Mouchette) and Bruno Dumont (La vie de Jésus). The film signals the emergence of an Irish cinema once again interested in the rural while acknowledging that the gap between the country and the city is no longer as clear, nor as distant, as it once was. It is an immensely engaging film told, like all their work, with great humanity and skill.

Garage has recently been released on DVD in Europe with plans to release in it the USA in 2009.

Tony Tracy: I'd like to begin by asking about the genesis of this film, what was the story you wanted to tell?

Mark O'Halloran: Well, I sat down to write it exactly a year to the day before we finished shooting it, so it was a very quick turnaround. Primarily it grows out of a number of stories from where I'm from in Ennis, Co Clare. I told Lenny about the central idea of the story - Josie living on his own and this boy coming into his life - and Lenny liked the idea a lot so I started to write.

What was the kernel of the story?

MOH: Well I wanted to write something about the Irish countryside because it's always represented in 
Irish cinema as being a big fat joke, and we're all mad and we all play banjos and that's it. And I kind of felt insulted by that because I'm from the country, and you wonder why is it being misrepresented so much? I got to thinking about the stereotypical village idiot, and thought that instead of this figure being peripheral we would shine the light on this character and show his life in a very honest way.

Lenny Abrahamson: And we also were interested in the idea of taking a very marginal and small life one that seems limited both in terms of the sphere of the character's action but also the internal life of the character. Or at least that's how it appears to the town. At a fundamental level we wanted in an honest an honourable way to rehabilitate a character that's just a sort of comedy staple in most films. To give him a three-dimensional life.

In terms of setting, Garage is the complete antidote to the squalid inner-city streets of Adam and Paul. Were you tempted to do something quite different with the second film together?

MOH: When I wrote Adam and Paul, people kept saying to me that my ear for Dublin dialogue was great, so, as a writer, I deliberately wanted to go in another direction. But for me, part of the attraction of writing of it was the memory of my youth.

One of the wonderful things about the writing is the way you catch the cadences of everyday small talk - the meaningless phrases and repetitions.

MOH: I just love listening to Irish people even saying hello to each other, "How are you," "yeah grand and yourself," "yeah not so bad" etc., and these words just go on and on and nobody is saying anything, but they take the time to speak to each other which is nice. I like the way that Irish people will pick up on a word which somebody says and they'll say it back to them and they'll continue on.

LA: It's interesting how people meet and talk to each other, and you might meet them later and they'll say I met so and so earlier and there's something not quite right with him there's something not good. But if you had heard their conversation all you would have heard was "so how's it going' yeah great....." and they would have talked about nothing and yet all that stuff was happening between the lines. So I think what Mark does really well is that he takes scenes and he defines that absent thing with all this seemingly insignificant stuff circling around it.

\section{It's all in the subtext.}

LA: Yeah exactly, and as a director you have to trust that the subtext is felt in the scene or else it'll collapse.

MOH: Subtext is important because I wanted to write something about male loneliness, because I think that men experience loneliness in a very different way to women; that men can isolate themselves in a way that women don't tend to. In Adam and Paul, for instance, there's a scene when Janine and the two lads are in the flat, I call that a love scene. It took forever to get that scene right, they are trying to say to each other that they love each other but they didn't have any other vocabulary so they can't ever say "I love you, I need you, I wish you were better for me," so what do you say then. There are scenes like that in Garage as well, for instance when Josie and Mr Skerrit are out by the lake they talk about pike and eels and the like but what it's really about is a man going "I'm afraid of the future and I'm afraid of the present and I'm afraid of the past and I think I'm going to die, and some other man saying "I don't know what to say but sure we're here anyway."

I think that's a very risky scene. Is there a danger that you can push this interest in subtext too far for an audience?

LA: Well some people do question it, or they say "what was that scene about"? They say that about the final scene in Garage for instance. But if we felt it hadn't worked it would have been cut. There are absences in every film - the things that didn't work and that can be for any number of reasons. But I wanted to go back to your question about the differences with Adam and Paul and while there are obviously huge differences, they are very much part of the same family stylistically. There is the circularity of dialogue that we spoke about. The more scripts you read, you notice the complete absence of how people actually speak - most scripts are incredibly artificial. You never get the real speech because someone will come along and say what is that doing there, how does that drive the plot forward, but yet I find that somehow if you do it right it can open up emotional territory that you just can't get to with a standard dramatic three-act. 
Josie has this refrain of "the oils the oils." It's a brilliant capturing of a character on the verge of taking possession of itself through "the oils," and of course it never happens. That's a promise that you then destroy it. And I suppose you're able to do that because you understand and trust each other so much that you can underwrite stuff.

MOH: Yeah, I think that's very important, if anyone else was to direct that it would be completely destroyed.

Speaking of directing styles, is Bresson a big influence? I see traces of Mouchette here.

LA: Well, I always go on about what a fan of Bresson I am. If I was to take one filmmaker that was to sum it up for me it would be Bresson. But actually I've seen very few of his films and I haven't seen Mouchette. Garage got a lot of comparisons to Bresson, that was massively satisfying, but it's not that conscious. I do love La vie de Jésus by Dumont. There is a shot in it where the lads are all out in the countryside. They get off their bikes and there's a bit of dialogue and then the camera lifts and you get a shot of the landscape. It's exactly where you would not expect; it's a deliberate directorial change of focus from the mundane and the particular to the existence of a world outside of the characters of the film. As a director I'm really fascinated about those shifts, you know, from the particular to the general or from where you are really just pointing at something in a dramatic context to something which means a complete shift of focus. And I also like the Dardenne brothers in the way they just follow their lead character which is something I've borrowed somewhat for here. Although the horse is clearly where that breaks and I intervene.

Let's talk a little bit about the way a script comes together and how you develop it. Garage is a series of episodes which are very loosely hung together in terms of plot. In preparing the script did you have a lot more episodes, did you find you needed more?

MOH: It's funny, with other scripts I've about 18 different versions on my computer, but with this one, just two drafts. It was always very strong, I knew what had to happen in the end. When I'd get up every morning I'd rewrite everything that I'd done the night before, so I was editing as I went along, and I'd start putting in layers. That's kind of how it evolved.

LA: There actually were a lot more scenes. But when you want to bunch the film into something as compressed as Garage you have to make the film and then start extracting bits in the edit, where you need to stay subtle or add where you need density.

MOH: I found with Adam and Paul, if you write very true characters, then an audience is going to stay with you even if the story arc isn't a conventional three-act structure. We learned that you can risk more and more as long as the character is speaking the truth and the people around him are reacting in exactly the way they should be reacting. An audience understands that there is a community at work here, so they can sit and watch it. You have to have a dramatic arc, but it can evolve on its own terms.

LA: The interesting thing is the way the internal structure of the film solidified, because it was only towards the end of the edit. Actually the first cut of the film was an hour longer than the finished film. I remember saying to Ed the producer "I actually think it's pretty good" but in fact you only discover how bad it is when you start to improve it. Three days before the end, after three months of post-production, I took ten minutes out of the film.

What did you take out?

LA: We took out two whole scenes and they were scenes that the film could live without. But we did have to find small structuring moments, so even though it's very bare you do learn in the first scene that the Garage is staying open, he meets the horse, there's the suggestion of the arrival of the guy to work with him. If you try to include some other suspense elements that are not going to be delivered on, a film like this can't handle them. We always say is that the first few minutes of our stuff is partially to educate the viewer about the pace and style of the film they're watching. In this case you jump into the garage in the film's very first shot after a very orchestrated musical opening. It's not particularly pretty, it's real time, just a hand-held shot. I tried various different ways into this film and then I decided I had to begin in the most ordinary possible way and then try to bring the film back through the hour and a half to the promise of that opening music and images.

Yes, that's terrific. You mentioned directing, and one of the things that strikes me in the film's style is that mix of hand-held and quite static, quite austere form of shooting. Can you talk a bit about that? 
LA: Well I like mixing styles, not in that post-modern way where you want the audience to know that you're doing it, I'm not interested in that. There's a scene in Adam and Paul where it goes completely silent and they hug each other, that's the only time in the film where that happens, so you're breaking all these rules about continuity. In Garage, there's the superficial layer, the superficial characterisation of Josie is just that he's a bit of a laugh and an idiot - that's the way the town sees him; and that's how we meet him at the beginning, and that develops into a much deeper portrait of a person who's interior is far too profound for us to ever understand, which is where I want the audience to be at the end.

So you've got the hand-held shots which communicate a certain kind of realism and immediacy and then you're punctuating that with this kind of austere or transcendental style which communicates a sort of stillness or inner life.

LA: That's right, that's what you're hoping to do. We had a lot more of that. In the original script Josie goes for lots of walks and in the end we reduced that to very little because we found that it was too telegraphed, too obvious.

So it's almost subliminally communicated.

LA: Absolutely, and it took a while, because you want the audience to feel is that they are reacting in a very undirected way, being allowed access to this character's life. I wanted all those other dimensions to Josie to be just like strings that you get underneath a melody. They begin really quietly so that you don't really notice them and then you gradually by the end - if the film works - you are overwhelmed by it. Then again, not everything is all planned; it's a sort of searching in the dark in the edit while you try to make that work. Initially we had a much more cyclical structure: he gets up, this is his day, he goes to sleep, then the next day he does it again. But we found that that could be communicated so simply.

What about the recurring appearance of the horse? How are we to interpret that?

LA: Well, the horse came about because of two things. I have to credit Michael West, a playwright who wrote this play called Foley, and in it there's a man feeding a horse and he talks about the feeling of the horses' breath on his hand. Secondly I saw a horse peering over a gate - as you do in Ireland and I wondered if we could include it in the script. Then Mark came up with this stuff about the apples which is so unusual and it links into his (non) relationship with Carmel. During the shoot I had this idea of going out into nature after he dies to sort of experience the world without him for a while, to meditate on his passing. And then we started to film this horse and I though we'd get maybe ten yards of the horse walking, started to walk right up the track to the lens and just looked at us with this incredibly powerful look. It was very profound. MOH: I think it's a very obvious metaphor, but what the horse did of its own volition at the end was something far more profound; it looks as if the horse is telling you that you've watched something...

Lets talk a little bit about music. You start with this beautiful, quite delicate piece and then it disappears for most of the film. Did you put music in and then take it back out, or how did that come about?

LA: Yeah, It's a bit similar to the way we work with everything really, like in the writing, Mark makes a point of not including the line that everyone would expect in any given scene. With the music I've worked with Stephen Rennicks on everything I've done and he wrote quite a lot of pieces for the film and we put them in each scene and we'd watch them and then one of us would go "why don't we just take it out again." And don't get me wrong I think the music is spectacularly good, there just isn't very much of it. We just kept taking things out. We have just one piece of music in the centre of the film, just after David has left, and there's this montage of shots of the sky. We put music there for two reasons, one, because it was a very different part of the film and it felt different, there was no forward motion.

MOH: I also think that there's an incredible nature soundtrack in the film, the sound of birds is incredibly loud. In the twenty-first century you can forget how loud birds can be.

There's an odd scene where you carry the outside sound over to the bar for quite a long time.

LA: Yes, it just felt right in the mix. It's just after David cycles away and I find the shot of Pat's face is amazing there. He just looks after the kid as he cycles home, and then we move into the bar and I wanted people to be still half in the scene before, so that sound carries over for just a few seconds.

It does that thing which you have spoken about, it's this kind of destabilising, yet as you 
say it carries over what has just happened, the sense of shame or confusion.

What's coming across from a lot of your decision making processes how you like to break the conventions of filmmaking. That's nowhere clearer than in the casting of Pat Shortt, who is very well known in Ireland as a loud, rambunctious comedian. When you were writing it, did you have him in mind?

MOH: Oh yeah, I wrote it especially for him, I think it would have been very difficult to make with anybody else, I couldn't think of anybody who would do it. I had once seen him from a distance in a bar. He was so animated when he was speaking to someone, but when he turned to his drink and there was nobody with him his face went incredibly still. And I just loved that moment, and that was kind of what made me go "that's him."

LA: And I had worked with him on a few things, like commercials. But I had also worked with him on this mad stuff he did with Jon Kenny, and I realised just how incredibly bright he is, and there is something that really great clowns have, and Pat's not the classic tears of a clown guy, he's actually just as happy in reality as he appears to be on screen, but there is a tenderness and an openness to his face when he's at rest which I think makes him be able to do that.

And where did he get his curious walk from?

LA: From his neighbour - the limp is from his neighbour, the arms are from someone else. I went down and spent quite a lot of time with him in Limerick just working on the character, just finding it really. So much of it is there in the dialogue but that's very different from finding the real concrete character. Pat was much better off the script so we improvised. It's funny, he's not a good reader of a script, so there was a worry about whether it would work, so I went down and spent 1 particular day with him in the studio and it was just really simple stuff. Improvising the role, there was stuff lying around the studio and he was lifting things up and checking and cleaning them as Josie. Then I would suggest things or be the other people in the script, and then it was completely and absolutely there. And then once he knew the scripts he was just so incredibly good.

I very much like the way you've given such depth to the supporting characters - people like the bar bully Breffini and the shop girl Carmel.

MOH: Well, I couldn't write a cipher or an empty one-dimensional character. Some people can but I just can't.

LA: If you're making a film as spare as this you have to really believe in every bit of it and see it through. I've been in enough edit suites to know that you can save something that isn't working with a cut or with music - you can manufacture the drama. But you can't do that here. There's nowhere to hide. So all the characters have to be fleshed out.

Adam and Paul was a very particular collaboration in that Mark, you also played one of the main characters - so you were on the set at all times. How did the collaboration work this time?

MOH: Well I have no desire to be a director but as a writer it's very hard to let go. It was a bit sad really I went to the first day of the shoot and there was no reason at all for me to be there. I really missed the fun of being part of the shoot. There are three distinct phases in the making of a film and I only want to be involved with the first one - the writing.

LA: We're lucky in that we trust each other. I don't subscribe to the view that the director's job is to realise the dream of the writer but we're really fortunate in that we both want to make the same film. If I had a really strong feeling that I didn't like what Mark was trying to do in a script how would I direct it?

I want to conclude by mentioning the scene near the end of the film where Josie makes tea for his boss - who is in fact just about to fire him. It's immensely powerful, largely on account of how much is left out in terms of exposition and dialogue.

LA: Well, it was interesting, because we shot a bit more but always with the idea that the scene would end up the way you see it. Partially we shot more just because it is always comforting to know that we got the rest of it there just in case your plan to truncate it doesn't work. But also for the actors, it allows them to play the full scene and not anticipate that end in their performance, so on the day they go through the full scene, we added in lines just so they could complete the scene. The way we tend to work is that we take out. It's not the only way to work - there are very valid ways to make films in a much more flamboyant and 
expressive way which lets the plot and characters develop. But the way we seem to be drawn to is to remove anything that isn't absolutely necessary.

Why have you opted to stay away from genre filmmaking - which is the starting point for so much recent Irish cinema?

MOH: When people make genre films here it tends to become about the genre and not the characters ... so you have scripts full of dialogue which fits with the genre but aren't really saying anything. That's the very opposite of what we want to do; character is everything.

[This interview took place at the Huston School of Film and Digital Media, NUI Galway.]

\section{Author Information}

Tony TRACY is Associate Director of Huston School of Film \& Digital Media, National University of Ireland, Galway. His publications include The Films of Edgar Ulmer, McFarland; "Caught Between a Rock (Hudson) and a Raparee: Captain Lightfoot's textual heritage," in Ruth Barton (ed.), Screening Irish America: Representing Irish America in Film and Television, Irish Academic Press (2009); "This Tempting Indulgence: William McGivern's Rogue Cops," in Matthew O'Brien and James Rodgers (Eds.), After the Flood, Irish America 1945-1960. Irish Academic Press (2009). 